\title{
BEYOND THE ARTERIES IN PERIPHERAL ARTERY DISEASE
}

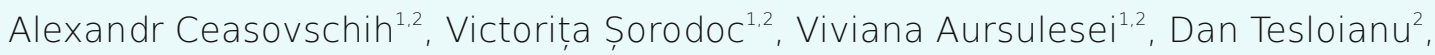 \\ Irina M. Jaba ${ }^{1}$, Corina Dima Cozma ${ }^{1,3}$, Bogdan M. Mihai ${ }^{1,2}$, Cristian Stătescu ${ }^{1,4}$, Oana Sîrbu $u^{1,2}$, \\ Alexandra Stoica ${ }^{1,2}$, Cristina Tuchiluș ${ }^{1,2}$, Ecaterina Anisie², Elena D. Grigorescu, ${ }^{1,2}$, \\ Lilia Simionov ${ }^{2}$, Maria Obreja ${ }^{1}$, and Laurențiu Șorodoc ${ }^{1,2}$ \\ ${ }^{1}$ Grigore T. Popa University of Medicine and Pharmacy, Iaşi \\ Emergency Clinical Hospital "Sf. Spiridon", Iaşi \\ ${ }^{3}$ Clinical Recovery Hospital, Iaşi \\ 4"Prof. Dr. George I. M. Georgescu" Institute of Cardiovascular Diseases, Iaşi \\ Correspondent author: \\ Lecturer Dr. Victorița Șorodoc, $2^{\text {nd }}$ Department of Internal Medicine, Emergency Clinical \\ Hospital "Sf. Spiridon" Iaşi, bd. Independenței, 1, Iaşi \\ E-mail:vivisorodoc@yahoo.com
}

\begin{abstract}
Objectives. This study aimed to examine peripheral artery disease severity impact on psychological profile of arteriopathy patients.
\end{abstract}

Material and methods. The prospective study included consecutive PAD patients admitted to the $2^{\text {nd }}$ Department of Internal Medicine and the Department of Cardiology of the Emergency Clinical Hospital "Sf. Spiridon" Iasi, between January and September, 2017.

Rezults. The group included 139 PAD patients, $80.6 \%$ male and $19.4 \%$ female, with an average age of 63.23 $\$ 9.44$ years. PAD stages have a very strong association with level of quality of life $(p<0.0001)$. All Leriche-Fontaine classification categories were significantly associated with the depressive symptoms $(p<0.0001)$. The stress level was moderate in stages IIA, IIB and III and extremely severe in the terminal stage. The prevalence of anxiety was lowest in incipient PAD stages with the highest value in stage III.

Conclusions. The fragment of the PhD study presented the psychological profile in the PAD staging and advocates a personalized, wide-ranging approach to the arteriopathy patient including pain and depressive-anxiety management, with a major impact on the quality of life at terminal stages. Keywords: peripheral artery disease, quality of life, depression, anxiety, stress.

\section{Rezumat}

Obiective. Studiul își propune evaluarea impactului severității arteriopatiei obliterante a membrelor inferioare asupra profilului psiho-emoțional al pacienților arteriopați.

Material and metodă. Studiul prospectiv a inclus pacienți arteriopați internați consecutiv în 


\section{INTERNAL}

\section{Original papers}

Clinica de Medicină Interna II și Clinica de Cardiologie a Spitalului Clinic Județean de Urgență "Sf. Spiridon" Iași, în perioada ianuarie - septembrie 2017.

Rezultate. Lotul a inclus 139 de pacienți cu AOMI, 80,6\% - bărbați și 19,4\% - femei, cu vârstă medie de 63,23 $\pm 9,44$ ani. Stadiile AOMI au avut o asociere foarte puternică cu nivelul calității vieții ( $p<0,0001$ ). Toate clasele Leriche-Fontaine au avut o asociere semnificativă $c u$ simptomele de depresie ( $p<0,0001)$. Nivelul de stres a fost moderat în stadiile IIA, IIB, III și extrem de sever în stadiul terminal. Prevalența anxietății a fost minimă în stadiile incipiente ale AOMI, cu cea mai mare valoare în stadiul III.

Concluzii. Corelarea profilului psihologic cu stadiile AOMI pledează pentru o abordare personalizată și amplă a pacientului cu arteriopatie, incluzând managementul durerii și depresiei, cu un impact major asupra calității vieții în stadiile terminale.

Cuvinte cheie: Arteriopatie obliterantă a membrelor inferioare, calitatea vieții, depresie, anxietate, stres.

\section{Introduction}

Peripheral artery disease (PAD) is one of the most frequent manifestations of generalized atherosclerosis, that occurs in $2-3 \%$ of the general population and accounts for $20 \%$ of all patients with cardiovascular diseases. The incidence of chronic atherosclerotic occlusive diseases of the lower limbs in patients under 60 years is $8-10 \%$, and in the age group over 60 years - $20 \%^{(1,2,3,4)}$. Currently, there is a tendency in increasing the number of patients with symptomatic PAD which is associated with "rejuvenation" of atherosclerosis, a demographic shift that determines a significant number of elderly and senile patients, an increase in the average life expectancy and an increase in risk factors for these diseases. Particular attention should be paid to the different ethiology of the disease, including changes in lipid metabolism, endothelial dysfunction, immune and hemostatic systems disorders. Atherosclerosis of the lower extremities arteries have tendency to constant progression, frequent amputation and disability, high lethality, which is associated with huge economic costs ${ }^{(5,6,7)}$.

In recent decades, the study of the quality of life, psycho-emotional status (depression, anxiety, stress) and other important subjective parameters of patient's health is 
recognized as a significant and relevant component of a comprehensive assessment of the effectiveness of treatment and of the prognosis in $\operatorname{PAD}^{(8,9)}$. The quality of life is an integral health indicator based on mathematical analysis, a logical approach and the principles of evidence-based medicine. At the same time, it is believed that the quality of life objectively reflects and unifies the person's perception of his physical, psychological, emotional and social functioning. The existence and importance of an association between depression, anxiety, stress and PAD remains insufficiently studied and limited $^{(10,11,12)}$.

Thereby, a widespread disability, a very low level of life quality, psycho-emotional disorders, unfavorable evolution and high mortality of this group of patients make the problem of PAD extremely actual.

\section{Objectives}

This study aimed to examine the psychological profile of patient's with peripheral artery disease and to evaluate potential factors of this association.

\section{Material and methods}

The prospective study included consecutive PAD patients admitted to the $2^{\text {nd }}$ Department of Internal Medicine and the Department of Cardiology of the Emergency Clinical Hospital "Sf. Spiridon" Iasi, between January and September, 2017. The demographic information, clinical assessment and comorbidities were obtained from the patient's examination and hospital medical records. The measurement of ankle brachial index $(A B I)$ was performed for all patients and PAD was defined as $A B I$ of $<0.9$. The clinical severity of PAD was assessed according to Leriche-Fontaine classification, which was divided by the clinical signs and symptoms. We investigated the patient's psychological profile using the following questionnaires: DASS 21-R (Depression, Anxiety and Stress Scales), STAI (State-Trait Anxiety Inventory) and Quality of Life Inventory. The psychological levels of severity were derived in some subcategories: life quality (average, low and very low), depression and stress (normal, mild, moderate, severe and extremely severe), DASS 21-R anxiety (normal, mild, moderate and severe) and STAI anxiety (normal, high and affective flattening). Written informed consent was obtained from all patients.

\section{Statistical method}

Baseline characteristics as well as the prevalence (\%) of impaired quality of life states were examined for the total sample and stratified by Leriche Fountaine Clasification. Z-test for column proportions followed by Bonferroni corrections for $p$ values was used to ascertain significant differences between frequencies in subgroups. Quality of life scores were presented as medians with $25^{\text {th }}$ and $75^{\text {th }}$ interquartiles (IQR). Medians between groups were compared using non-parametric tests (Kruskal-Wallis, Mann Whitney U). Measures of associations were studied using Cramer's V (nominal by nominal) coefficient. Data analysis was performed using IBM SPSS Statistics for Windows (version 20). All tests were two-tailed and a $p$-value $<0.05$ was considered statistically significant.

\section{Results}

The group included 139 PAD patients, $80.6 \%$ male and $19.4 \%$ female, with an average age 


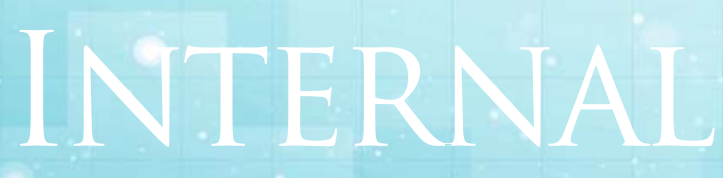

Original papers

of $63.23 \pm 9.44$ years, of which $74.5 \%$ were smokers. The documented comorbidities involved dyslipidemia (90.6\%), hypertension (89.2\%), chronic kidney disease $(70.5 \%)$ and diabetes mellitus (41.7\%). Baseline characteristics for the subgroups sample, stratified by Leriche-Fontaine classification are presented in Table 1.

Life quality estimated by Quality of Life Inventory Questionnaire showed that arteriopathy patients had scores that varied between average - 53 (38.15\%), low - 33 (23.7\%) and very low level - 53 (38.15\%). Predictably, data processing shows that PAD stages have a strong and significant association with the level of quality of life (Cramer's V 0.557, $\mathrm{p}<0.0001$ ). The number of patients that get low and very low level scores increases significantly as the severity of PAD stages increases (Figure 1, Table 2).

Depression symptoms were observed in 67 (48.2\%) patients and were divided into the following subgroups of severity: mild severity level - 15 (10.8\%), moderate - 12 (8.6\%), severe - $17(12.25 \%)$ and extremely severe $23(16.55 \%)$. All Leriche-Fontaine classification categories were significantly associated with depressive symptoms (Cramer's V 0.468, p<0.0001), (Figure 2a). Causes of depression included lower limb pain, limitation of motion independence and high amputation risk. For total sample, the prevalence of stress symptoms was $64 \%$. Out of this, $26.6 \%$ had mild stress severity levels, $15.1 \%$ moderate, $17.3 \%$ severe and $5 \%$ had extremely severe stress symptoms scores. As expected, the stress severity levels recorded were moderate for stages IIA, IIB and III and extremely severe in the terminal stage (Figure $2 b$ ).

The prevalence of anxiety ranged from $0.7 \%$ to $11.5 \%$ in DAAS $21-R$ and from $20.1 \%$ to $57.6 \%$ in STAY Y questionnaires, being lowest in incipient PAD stages with the highest value in stage III (Figure $2 \mathrm{c}, \mathrm{d}$ ).

Scores on quality of life inventory and DASS 21-R questionnaires showed very significant differences between PAD groups, which was not observed in the STAY questionnaire (Table 3).

\section{Discussions}

Until recent decades, the severity and evolution of PAD, inclusive effectiveness of treatment, were determined by the modification of clinical manifestations and paraclinicals parameters of peripheral arteries atherosclerosis. Currently, this approach is considered insufficient, and new methods of managing the course of PAD include an assessment of the psychological profile and the identification of indicators of the life quality for each patient individually ${ }^{(9,10,12,13)}$. The quality of life includes physical, emotional and social status of the 


\begin{tabular}{|c|c|c|c|c|c|c|}
\hline Characteristic, n (\%) & Stage I & Stage IIA & Stage IIB & Stage III & Stage IV & $p$-value \\
\hline Total group sample & $6(4.31)$ & $40(28.77)$ & $53(38.12)$ & $21(15.1)$ & $19(13.66)$ & N/A \\
\hline Age, mean (SD) & $76.33(6.47)$ & $\begin{array}{c}71.15 \\
(10.04)\end{array}$ & $67.94(8.62)$ & $\begin{array}{c}68.48 \\
(10.25)\end{array}$ & $67.37(9.38)$ & 0.14 \\
\hline Male gender & $6(4.31)$ & $30(21.58)$ & $40(28.77)$ & $20(14.38)$ & $16(11.51)$ & 0.19 \\
\hline Residence, urban & $4(2.87)$ & $17(12.23)$ & $15(10.79)$ & $4(2.87)$ & $16(11.51)$ & 0.159 \\
\hline Sedentarism & $1(0.71)$ & $16(11.51)$ & $18(12.94)$ & $8(5.75)$ & $7(5.03)$ & 0.845 \\
\hline Cigarette smoking & $3(2.15)$ & $27(19.42)$ & $43(30.93)$ & $17(12.23)$ & $14(10.07)$ & 0.196 \\
\hline Hypertension & $6(4.31)$ & $39(28.05)$ & $49(35.25)$ & $14(10.07)$ & $16(11.51)$ & $<0.004$ \\
\hline Diabetes & $2(1.43)$ & $19(13.66)$ & $21(15.1)$ & $7(5.03)$ & $9(6.47)$ & 0.797 \\
\hline Dyslipidemia & $6(4.31)$ & $35(25.17)$ & $47(33.81)$ & $20(14.38)$ & $18(12.94)$ & 0.697 \\
\hline Anemia & 0 & $12(8.63)$ & $18(12.94)$ & $6(4.31)$ & $11(7.91)$ & 0.077 \\
\hline Chronic kidney disease & $5(3.59)$ & $28(20.14)$ & $41(29.49)$ & $12(8.63)$ & $12(8.63)$ & 0.482 \\
\hline
\end{tabular}

Table 1. Baseline characteristics for the total sample $(n=139)$ and stratified by Leriche-Fontaine classification SD, standard deviation;

\begin{tabular}{|c|c|c|c|c|c|c|}
\hline & & \multicolumn{5}{|c|}{ Leriche Fontaine Classification (PAD stages) } \\
\hline & & stage I & stage IIA & stage IIB & stage III & stage IV \\
\hline \multirow{3}{*}{$\begin{array}{l}\text { Quality of life } \\
\text { inventory }\end{array}$} & average level & $5 a$ & $26 a$ & $22 a$ & $O_{b}$ & $O_{b}$ \\
\hline & low level & $1 a, b$ & $12 a, b$ & $18 b$ & $2 a, b$ & $\mathrm{O}_{\mathrm{a}}$ \\
\hline & very low level & $0_{a}$ & $2 a$ & $13 a$ & $19 b$ & $19 b$ \\
\hline
\end{tabular}

Table 2. Number of patients in quality of life subgroups accordingly to PAD stages

Each subscript letter denotes a subset of Leriche Fontaine Classification categories whose column proportions do not differ significantly from each other at the 0.05 level.

patients and is an objective criterion for an additional integrated indicator of the selected treatment regimen evaluation, as well as the evolution and prognosis of PAD. The main reason for the decline in the life quality is persistent disability in $15-50 \%$ of PAD patients, often at a working age, and in $5-40 \%$ of cases the progression of this process determines the need for amputation of the affected limbs in the first 5 years from the time of PAD diagnosis. One of the complexities of an integrated assessment of life quality in PAD is the frequent discrepancy between objective indicators of patient's disabilitation and subjective determination of his state of health. These processes of 


\section{INTEF}

\begin{tabular}{|l|c|c|c|c|c|c|}
\hline $\begin{array}{l}\text { Characteristic, median } \\
\text { (IQR 25-75) }\end{array}$ & Stage I & Stage IIA & Stage IIB & Stage III & Stage IV & $p$-value \\
\hline Total group sample, $\mathrm{n}(\%)$ & $6(4.31)$ & $40(28.77)$ & $53(38.12)$ & $21(15.1)$ & $19(13.66)$ & NA \\
\hline Quality of life inventory & $2(2-2.25)$ & $2(2-3)$ & $3(2-3.5)$ & $4(4-4)$ & $4(4-4)$ & $<0.0001$ \\
\hline $\begin{array}{l}\text { Depression severity level } \\
\text { (DASS 21-R) }\end{array}$ & $1(1-1)$ & $1(1-1)$ & $1(1-2)$ & $4(4-5)$ & $5(5-5)$ & $<0.0001$ \\
\hline $\begin{array}{l}\text { Stress severity level } \\
\text { (DASS 21-R) }\end{array}$ & $2(1-2)$ & $1(1-2)$ & $2(1-2)$ & $4(3-4)$ & $4(4-5)$ & $<0.0001$ \\
\hline $\begin{array}{l}\text { Anxiety severity level } \\
\text { (DASS 21-R) }\end{array}$ & $1(1-1.25)$ & $1(1-1)$ & $1(1-1)$ & $1(1-2)$ & $3(1-3)$ & $<0.0001$ \\
\hline $\begin{array}{l}\text { State anxiety score } \\
\text { (STAl forma Y) }\end{array}$ & $2.5(1-3)$ & $2(1-3)$ & $2(1.5-2)$ & $2(2-2)$ & $2(2-2)$ & 0.951 \\
\hline
\end{tabular}

Table 3. Patient's psychological profile and quality of life in subgroups of Leriche-Fontaine classification

calculating the subjective part of life quality are often affected by the psychological state of the atherosclerotic patient, which includes depression, anxiety and stress ${ }^{(14,15,16)}$.

Causes of psycho-emotional disorders included persistent lower limb pain, limitation of motion independence, high amputation risk and association of comorbidities constellation ${ }^{(10,13,15,16)}$. From the pathophysiological point of view, impaired mood can be a trigger that aggravates the inflammatory processes in the atherosclerotic focus using stimulation mechanisms in activation of sympathetic nervous system, synthesizing proinflammatory cytokines (interleukin-1, tumor necrosis factor, lymphocyte function-associated antigen 1 , et al.). Neuroendocrine and immune disorders which occur in depression and stress, contribute to the elevations of sympatho-adrenal activity which affects blood vessels and platelets, and determine a rapid and unfavorable evolution in arteriopathy patients. Recent scientific evidence affirm that primary immunological response leads to vessel tissue damage which result in the atherogenesis aggravation and this process is much expressed in PAD patients with impaired mood and psycho-emotional disorders ${ }^{(17,18)}$. 


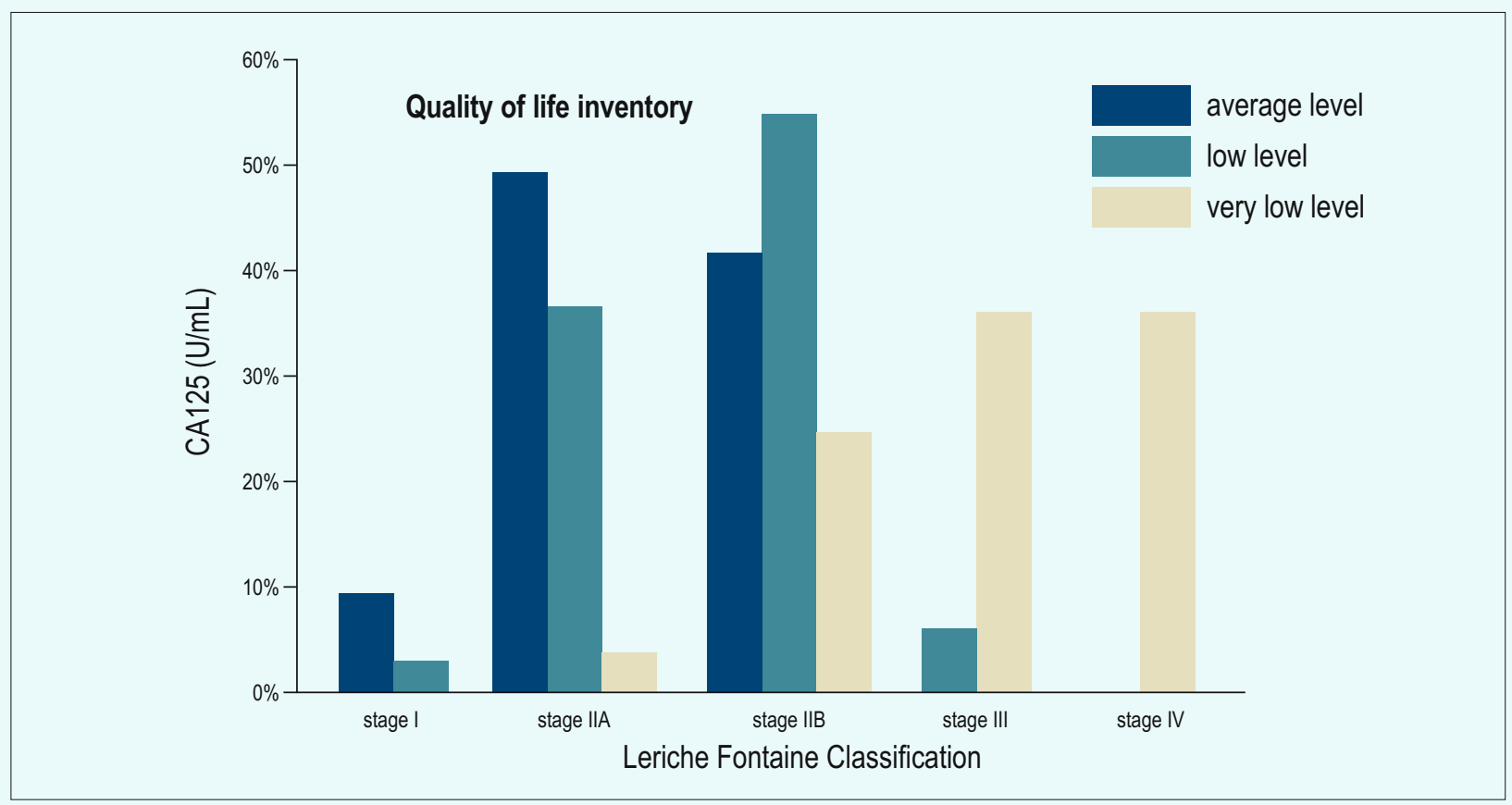

Figure 1. Patient's quality of life profile in subgroups of Leriche-Fontaine classification

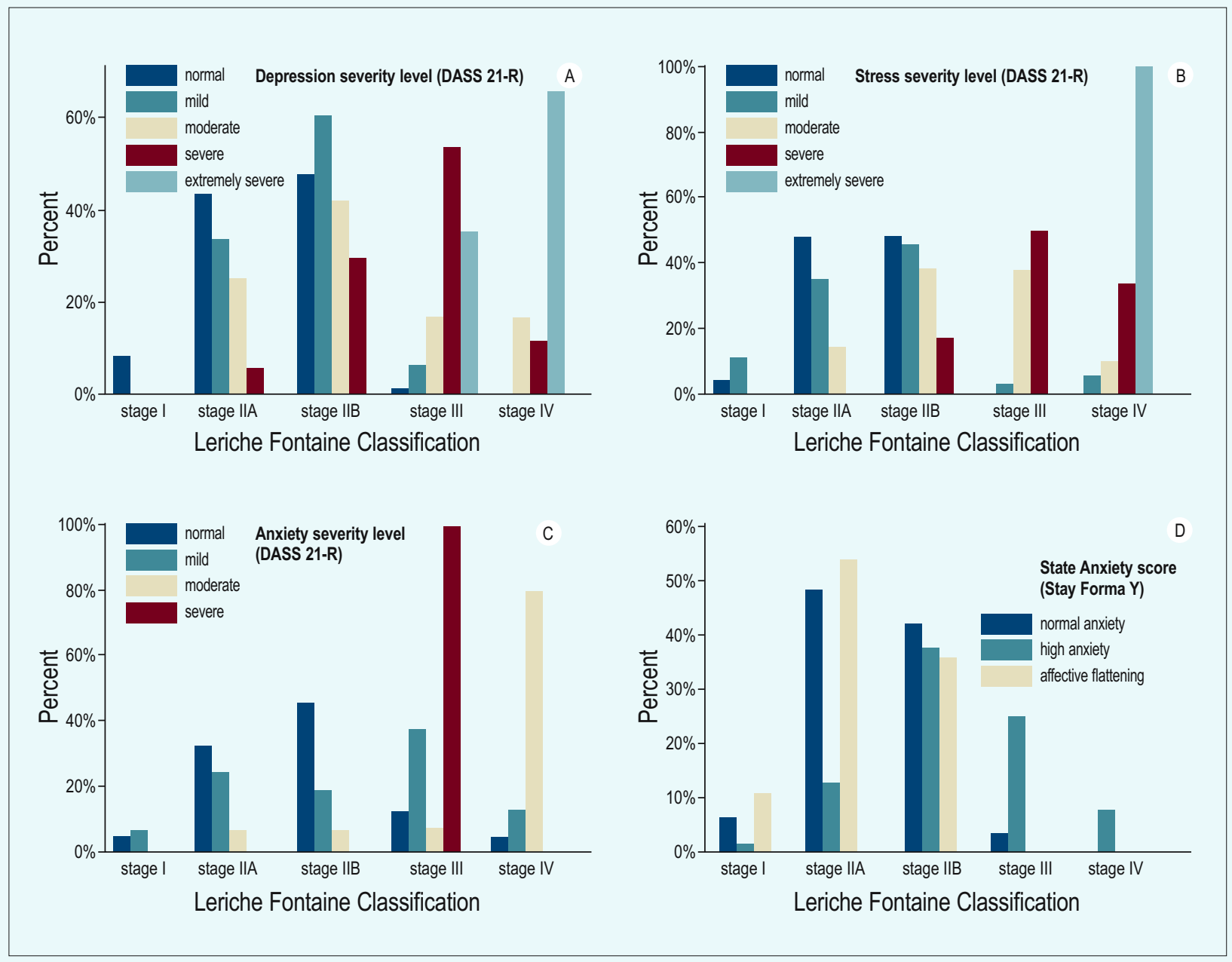

Figure 2. Patient's psychological profile: a - depression severity, $b$ - stress severity, c - anxiety severity DASS 21 $R, d$ - anxiety severity STAY, in subgroups of Leriche-Fontaine classification 


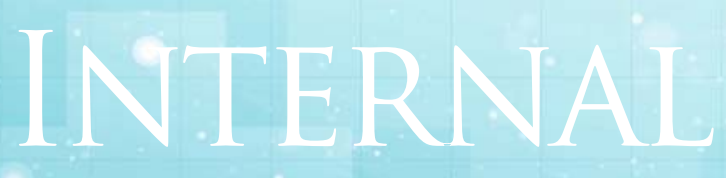

Original papers

In accordance with other results, our study have a potential similar associations between PAD and psycho-emotional status including life quality, although different questionnaires have been used (Hospital Anxiety and Depression Scale, Sun Diego Claudication Questionnaire, 9-items Patient Health Questionnaire, QOL scores, Geriatric Depression Score, et al. $)^{(9,15,19,20)}$. Impact of different treatment options on life quality was also assessed by different studies. A Sweden study which investigated the impact on life quality (HRQoL) of primary stenting comparative with best medical treatment in patients with PAD, showed that primary stenting was associated with significant improvements in HRQoL durable up to 24 months of follow-up ${ }^{(21)}$.

In connection with the above data, both general and specific methods for assessing the life quality and psycho-emotional status are of great value, helping doctors in calculating and monitoring the effectiveness of conservative, interventional and surgical treatment, including non-drug treatment and post-operative rehabilitation methods.

\section{Conclusions}

The fragment of the PhD study presented the psychological profile in the PAD staging and advocates a personalized, wide-ranging approach to the arteriopathy patient including pain and depressive-anxiety management, with a major impact on the quality of life in terminal stages. The holistic approach addresses the patient with all his problems and not just the arterial disease, which is why the arteriopathy patient should be seen as an indivisible whole.

\section{Bibliography}

1. Aboyans V., Ricco J.B., Bartelink M.E.L. et al. 2017 ESC Guidelines on the Diagnosis and Treatment of Peripheral Arterial Diseases, in collaboration with the European Society for Vascular Surgery. Eur Heart $\mathrm{J}$, 2018: 39(9): 763-816.

2. Gerhard-Herman M.D., Gornik H.L., Barrett C., et al. 2016 AHA/ACC Guideline on the Management of Patients with Lower Extremity Peripheral Artery Disease: Executive Summary. Circulation, $2017 ; 135$ (12): e726e779.

3. Aboyans V., Sevestre M.A., Désormais l., et al. Épidémiologie de l'artériopathie des membres inférieurs. Presse Med, 2018; https://doi. org/10.1016/j.Ipm.2018.01.012.

4. Fowkes F.G., Aboyans V., Fowkes F.J., et al. Peripheral artery disease: epidemiology and global perspectives, 2016; doi:10.1038/nrcardio.2016.179

5. Aber A., Lumley E., Phillips P., et al. Themes that Determine Quality of Life in Patients with Peripheral Arterial Disease: A Systematic Review. Patient, 2018; doi.org/10.1007/s40271-018-0307-7.

6. Conte S.M., Vale P.R. Peripheral Arterial Disease. Heart, Lung and Circulation, 2017; https://doi.org/ 10.1016/j. h/c.2017.10.014.

7. Morley R.L., Sharma A., Horsch A.D., et al. Peripheral Arterial Disease. BMJ, 2018; doi: 10.1136/bmj.j5842.

8. Davie-Smith F., Coulter E., Kennon B., et al. Factors influencing quality of life following lower limb amputation for peripheral arterial occlusive disease: $A$ systematic review of the literature. Prosthetics and 
Orthotics International, 2017; 41 (6): 537-547.

9. Smolderen K.G., Hoeks S.E., Pedersen S.S., et al. Lower-leg symptoms in peripheral arterial disease are associated with anxiety, depression, and anhedonia. Vascular Medicine, 2009; 14: 297-304.

10. Arya S., Lee S., Zahner G.J., et al. The association of comorbid depression with mortality and amputation in veterans with peripheral artery disease. J Vasc Surg, 2018; doi.org/10.1016/j.jvs.2017.10.092

11. de Almeida Correia M., Andrade-Lima A., Mesquita de Oliveira P.L., et al. Translation And Validation Of The Brazilian-Portuguese Short Version Of Vascular Quality Of Life Questionnaire In Peripheral Artery Disease Patients With Intermittent Claudication Symptoms, Annals of Vascular Surgery, 2018; doi: 10.1016/j.avsg. 2018.02.026.

12. Harwood A.E., Totty J. P., Broadbent E., et al. Quality of life in patients with intermittent claudication. Gefässchirurgie, 2017; 22: 159-164.

13. Wu A., Coresh J., Selvin E., et al. Lower Extremity

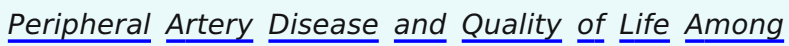
Older Individuals in the Community. J Am Heart Assoc, 2017; 6: e004519. doi: 10.1161/JAHA.116.004519.

14. Brostow D.P., Petrik M.L., Starosta A.J., Waldo W.S. Depression in patients with peripheral arterial disease: $A$ systematic review. European Journal of Cardiovascular Nursing, 2017; 16(3): 181-193.

15. Grenon S.M., Hiramoto J., Smolderen K.G., et al.
Association Between Depression and Peripheral Artery Disease: Insights From the Heart and Soul Study. J Am Heart Assoc, 2012; 1:e002667, doi: 10.1161/JAHA. 112. 002667

16. Gardner A.W., Waldstein S.R., Montgomery P.S., et al. Effect of cognitive status on exercise performance and quality of life in patients with symptomatic peripheral artery disease. J Vasc Surg, 2016; 63 (1): 98-104.

17. Wright C.E., Strike P.C., Brydon L., Steptoe A. Acute inflammation and negative mood: mediation by cytokine activation. Brain Behav Immun, 2005; 19: 345-350.

18. Irwin M. Psychoneuroimmunology of Depression: Clinical Implications. Brain, Behavior, and Immunity, 2002; 16: 1-16.

19. Ustundag H., Gul A., Findik U.Y. Quality of Life and Pain in Patients with Peripheral Arterial Disease. InternationalJ of Caring Science, 2016; 9 (3): 838-845.

20. McDermott M.M., Guralnik J.M., Tian L., et al. Incidence and Prognostic Significance of Depressive Symptoms in Peripheral Artery Disease. J Am Heart Assoc. 2016; 5:e002959 doi: 10.1161/JAHA.115.002959 21. Lindgren H., Qvarfordt P., Bergman S., et al. Primary Stenting of the Superficial Femoral Artery in Patients with Intermittent Claudication Has Durable Effects on Health-Related Quality of Life at 24 Months: Results of a Randomized Controlled Trial. Cardiovasc Intervent Radiol, 2018; 41 (6): 872-881. 